\begin{tabular}{ccc}
\hline & International Journal of Engineering \& Technology, $7(3.30)(2018) 405-408$ \\
SPC & International Journal of Engineering \& Technology \\
\hline
\end{tabular}

\title{
The Pattern of Communication Legal Advisor with Defendant In Indonesian Courtroom
}

\author{
Aan Widodo ${ }^{1 *}$, Dadang Rahmat Hidayat ${ }^{2}$, Anter Venus ${ }^{3}$, Sigid Suseno ${ }^{4}$ \\ ${ }^{1}$ University of Bhayangkara Jakarta Raya, University of Padjadjaran \\ ${ }^{2}$ University of Padjadjaran \\ ${ }^{3}$ University of Padjadjaran \\ ${ }^{4}$ University of Padjadjaran \\ *Corresponding author E-mail: aan.widodo@dsn.ubharajaya.ac.id
}

\begin{abstract}
This article aims to illustrate the pattern of communication between legal Advisor and the defendant in court as one form of communication in the courtroom. This study addresses the research question: how is the communication pattern of legal advisor with the defendant in the courtroom at the Central Jakarta District Court. This research uses qualitative research approach, research method is ethnography of communication, with an interpretive paradigm. The results of this study indicate that communication between the legal advisor with the defendant in the courtroom begins at the time of the indictment hearing, the hearing, the prosecution and the verdict. The form of communication that emerged in the trial process through advocacy. Advocacy is a form of communication of legal Advisor with the defendant, with the primary objective of providing an understanding to the defendant about the legal information and the punishment that the defendant will receive.
\end{abstract}

Keywords: Communication, Lawyer, a defendant, courtroom, advocacy.

\section{Introduction}

The examination of the defendant's rules in the trial process requires the defendant to be accompanied by a legal advisor when the defendant's lawsuit is at least 5 years. The rule is set out in the Criminal Code. 81 of 1984. (1) On that basis, every defendant who has a crime with a minimum penalty of 5 years is required to be accompanied by a legal Advisor. For defendants who are under penalty of fewer than 5 years, they are not required to be accompanied by a legal Advisor but have the same rights to obtain legal aid accompanied by legal Advisor.

The Legal Advisor has the duty to assist the accused in undergoing legal proceedings from investigation, investigation, to trial in court. The Legal Advisor has the function of providing legal assistance to the Defendant, and the Defendant receives legal aid from the Legal Advisor. Law No. 4 of 2004 on Judicial Power, Chapter VII article 37 on legal aid states that everyone who is caught up in the matter is entitled to legal aid. In the criminal case, a person has been suspect since the arrest and/or arrest has the right to contact and request the assistance of a legal Advisor. In providing legal assistance, the Legal Adviser is obliged to assist the settlement of the case by upholding the law and justice.(2)

The Legal Advisor with the Defendant in the trial process is involved in the communication process. The communication process takes place in court hearings. In the Central Jakarta District Court, the communication of the Legal Advisor with the Defendant is depicted in the process of criminal investigation, the process starts from the indictment, the prosecution, the hearing, and the verdict. Several points indicate the involvement of the Legal Advisor with the Defendant in the hearing, the relationship between the Legal
Advisor and the Defendant is described as a drama in a drama trial which the defense Advisor has committed against the examination (3), in the face of the examination of legal Advisor with the defendant having a number of differences in some of the trials, (4) One of the trials that took place in the judicial process at the Central Jakarta District Court occurred in the trial of Jessica Kumala Wongso. The Jesicca trials can be viewed as a drama in the examination of the case. This is reflected from the activities of communication conducted. From these activities can be described there are acts of communication conducted by the Legal Advisor with the defendant, the act is done repeatedly to obtain legal justice. From the process of the trial formed a habit in communication, from the habit of becoming a culture.

In cultural perspectives, the practice performed in the trial is a culture (5). So it can be said through the communication activities of legal Advisor with the defendant is a habit that has a certain pattern or element that can be explained. As illustrated in the press stage of the defendant's trial in the general criminal proceedings in the courtroom by the Panel of Judges, Public Prosecutors, Legal Advisors, Defendants, Witnesses, and visitors.

From a communications perspective, the habit of a legal Advisor with a defendant in a criminal trial involves the concept of communication viewed as a communication process $(6,7)$. From the process involves the process of meaning exchange through communication done in order to achieve the objectives of legal justice. This study is different from other research, which explains the communication pattern of legal Advisor with the defendant formed a series of the communication process. This becomes important, given the legal nature of the defendant is one of the responsibilities of legal Advisor, so that through the explanation of this communication pattern can compare the communication communication pattern that occurred in the trial. 


\section{Literatur Review}

\subsection{Communication}

Communication is defined as the process of transferring information from one source to another. Later on, a wider scale communication can also be translated as a social process whereby individuals use various symbols to create or interpret meanings in their environment. Communication becomes an important part of the trial, as a dimension that communication can happen anywhere and anytime (8). Courtroom communication involves various parties as a communicating group with communicated aims and messages. Communicating messages occur in both verbal and nonverbal forms.

\subsection{Ethnography Communication}

Ethnography is rooted in anthropology, which is a researcher's activity to understand how people interact and work together through the observed phenomena of everyday life (5). Ethnography is the combined term of the word ethnic (nation) and graph (decipher). Ethnography aims to understand the point of view of indigenous peoples in relation to the activities of everyday life, namely "to grasp the native's point of view, his relation to life, to realize his vision and his world." An understanding of ethnography will give the world an angle the view of indigenous people so that ethnography in addition to studying the community is a process of learning from the community $(9,10)$

The ethnography of communication was originally called ethnography of speaking by Dell Hymes in 1962. The purpose of Hymes' approach was to analyze discourse centered on the role of communication in human behavior. Then in 1964, Hymes changed the name of his perspective into an ethnography of communication in order to better express the use of context-dependent nonvocal (eg, murmur) and nonverbal (eg gesture, silent) communications (11). The ethnography of communication is a study of the communication patterns of a cultural community. By macro, this study is part of ethnography. Ethnography of communication (ethnography of communication) is the development of Ethnography of speech, which was put forward by Dell Hymes in 1962 (12).The study of communication ethnography is aimed at studying the role of language in the communicative behavior of a society. It is about the ways in which language is used in different societies.

Ethnography Communication (Ethnography of Communication) is an approach to analyze a discourse used. This approach is based on anthropology and linguistics. This approach focuses on a variety of communicative competences in speech communities, patterned communication and organized as a communicative event system and ways of interacting with other cultural systems (13). This approach seeks to:

a. Find the different forms and functions available to communicate

b. Deciding how these forms and functions become part of a different way of life.

c. Analyze communication patterns as part of cultural and behavioral knowledge.

To illustrate and analyze Hymes communication (13) divides into three units of analysis, including situations, events, and acts. The communicative situation is the context in which communication takes place such as ceremonies, fights, hunting, classroom learning, conferences, parties and so on. Communicative events (communicative events) are the basic units for a descriptive purpose of the same communication include same topic, same participants, same language variety. The communicative act is generally adjacent to a single interactional function, such as a referential statement, request, or order, which may be a verbal or nonverbal act. The use of ethnographic communication in the behavior and communication process between the legal Advisor and the defend- ant in the courtroom is aimed at studying the community groups, the evolving ways of communicating as the law enforcers understand through spoken language and symbols that lead to communication action. Other than that, the study of the socio-cultural context of communication will provide a picture of the diversity of characteristics of community groups spoken in court as groups that have the same "language" in communicating through verbal interaction.

\subsection{Communication Pattern}

Communication pattern is a simple description of the communication process that shows the relationship between one communication component with other components. The pattern of communication is defined as the form or pattern of the relationship of two or more people in the process of sending and receiving messages in a proper way so that the message in question can be understood. Communication Pattern is a process designed to represent the reality of the interconnected elements and its sustainability, in order to facilitate systematic and logical thinking (14). Based on this understanding, the communication pattern intended in this study is to describe the pain of communication components in the trial, as a communication in the trial.

\section{Methodology}

This research will utilize a qualitative research qualitative with Ethnographic Communication research method. Qualitative research is a research process to understand the phenomenon that is based on research tradition with a unique method, which examines the problems of people and society. Researchers build complex and holistic images, analyze words, report informant views in detail and conduct research in a natural outlook. (15).Departing from this understanding, this research was conducted with the aim to explain the detailed description related to the Communication Pattern of Legal Advisor with the defendant in the session, the Central Jakarta District Courtroom.

This research was conducted at the Central Jakarta District Court. Informants to be studied are the researcher's choice to explain and answer the research objectives. Informant research is a subject that understands the object of research both as the perpetrator and others who understand the object under study(5). A technique used in determining a source of data/informant by using purposive sampling. (16),Purposive sampling is a technique of taking data sources with certain considerations. This particular consideration, for example, the person is considered the most knowledgeable about what to expect, or maybe he as a ruler so that it will allow researchers to explore objects or social situations to be studied. Based on these considerations to determine the informant field, which consists of legal Advisor and defendant.

Data collection is done by invoking three data collection techniques, as revealed by (17)ie In-depth interview, Participatory Observation, Library Studies. This research will emphasize indepth interviews to describe the situation, the events by the informants about the situation or the consciousness of the object under study, by focusing on the Legal Advisor's communication with the defendant. While participatory observation will be conducted in the central courtroom of central Jakarta at the time of the hearing took place by looking and taking note what happened in relation to the object of the researcher thoroughly. Research data that has been collected through data collection techniques will then be analyzed. Data analysis was conducted qualitatively based on facts and information collected by prioritizing representative searches to avoid bias data $(6,18)$. Data will be reviewed through concept concepts or theories used in research in accordance with the rules of Ethnography Communications. The stages of data analysis are the data generated will be done Reduction of data (data reduction), meaning all data or information that the authors obtain the field will be taken part of the object under study so that 
it becomes part of the themes to be explained. Then after the author data selected according to the theme, will be presented and describe and analyze based on the concept or theory used (display data). In the end after discussion based on field situation and concepts will be drawn Conclusion.

Central Jakarta District Court is located at Jalan Bungur Besar No. 24,26,28, Kemayoran, Central Jakarta. PN Jakpus is located in the center of Jakarta, exactly about five-kilometers from the central government of the Unitary State of the Republic of Indonesia. The Central Jakarta District Court is one of the first tribunals within the General Courts within the jurisdiction of Central Jakarta Municipality.

\section{Result and Findings.}

The research on the pattern of communication of legal Advisor with the defendant in the trial was conducted at the Central Jakarta District Court focusing on the communication process that occurred in the general criminal proceedings. The trial has a communication dimension where the trial process involves various parties exchanging messages to achieve the objective of validating a case. Some of the parties involved are the Panel of Judges, Defendants, Legal Advisors, Public Prosecutors, Witnesses. Based on the focus, communication involvement in this research occurred between legal Advisor with the defendant, through verbal and nonverbal communication.

\subsection{The Criminal Trial Process in the Courtroom}

The focus in communication research results in criminal trials in the public courtroom is communication activity. As the concept or definition of communication activity above, the communication activity in question is communication activity of communication actors in the central courtroom of Central Jakarta. As the results of the field, communication activities are obtained from criminal proceedings in both general and special criminal cases in court The following is a summary of the court process or stages of criminal proceedings as described in the previous Chapter.

Based on the 1981 Criminal Procedure Code, the hearing can be conducted through a series of stages as reflected in the observation result in court case No. 777 / PID.B / 2016.PN.JKT / PST. And based on UU.No. 8 of 1981 on trial of criminal cases in public courts, in general, are set in per KUHAP which outline consists of four stages as follows:

Table 1.1: Stages of the Trial Based on Law no. 8 of 1981 of the Criminal Code.

\begin{tabular}{|c|c|c|c|}
\hline \multicolumn{4}{|l|}{ Stages of the Trial } \\
\hline Early & Inspection $\operatorname{Prc}$ & & End \\
\hline First Session & $\begin{array}{l}\text { Proof of } \\
\text { Assembly }\end{array}$ & $\begin{array}{l}\text { Claim } \\
\text { Session }\end{array}$ & Judgment Session \\
\hline $\begin{array}{l}\text { On the day of the trial } \\
\text { which has been set by } \\
\text { the judge/judge, the } \\
\text { hearing of the exami- } \\
\text { nation of the case } \\
\text { includes the reading } \\
\text { of the indictment, the } \\
\text { filing of an exception } \\
\text { (objection), the read- } \\
\text { ing/pronunciation of } \\
\text { the interlocutory } \\
\text { decision. }\end{array}$ & $\begin{array}{l}\text { If the } \\
\text { judge/panel } \\
\text { of judges } \\
\text { determines } \\
\text { that the court } \\
\text { hearing } \\
\text { should be } \\
\text { continued } \\
\text { then the trial } \\
\text { proceeds to } \\
\text { the stage of } \\
\text { proof of } \\
\text { examination } \\
\text { of evidence } \\
\text { and evidence } \\
\text { presented. } \\
\text { Examination } \\
\text { of the de- }\end{array}$ & $\begin{array}{l}\text { Session of } \\
\text { Criminal } \\
\text { Litigation, } \\
\text { Defense, } \\
\text { And Re- } \\
\text { sponse } \\
\text { Feedback }\end{array}$ & $\begin{array}{l}\text { Before passing } \\
\text { the judge's judg- } \\
\text { ment considera- } \\
\text { tion based on a } \\
\text { letter of defama- } \\
\text { tion, everything } \\
\text { that is proven in } \\
\text { court, criminal } \\
\text { charges, plea, and } \\
\text { response. If the } \\
\text { case is handled } \\
\text { by the panel of } \\
\text { judges, the basis } \\
\text { of the considera- } \\
\text { tion should be } \\
\text { deliberated by the } \\
\text { judges after the } \\
\text { decision is ready }\end{array}$ \\
\hline
\end{tabular}

\begin{tabular}{|l|l|l|l|}
\hline Stages of the Trial & \multicolumn{3}{|l|}{} \\
\hline Early & $\begin{array}{l}\text { Inspection Proces } \\
\text { Assembly of }\end{array}$ & $\begin{array}{l}\text { Claim } \\
\text { Session }\end{array}$ & Judgment Session \\
\hline First Session & $\begin{array}{l}\text { fendant and } \\
\text { witness. }\end{array}$ & & to be read \\
\hline
\end{tabular}

Based on this stage of the trial, the communication process becomes the main thing, one of which relates to legal Advisor with the defendant in the courtroom. Communication of legal Advisor with the defendant in the courtroom takes place in every stage. The stages consist of (1) First Session, (2) Evidence Session, (3) Session of Claims, (4) Session of Judgment.

\subsection{Communication Activities of the Legal Advisor with the Defendant in the Courtroom}

Communication activity is an integral part of human life. The concept of communication activity is related to a series of individual or group activities, in actualizing themselves in their life through communication. As one of the principles of communication (7) that each activity is a dimension or symptom of communication. The dimension or symptom of communication arises from the view of communication as a process $(8,19)$ from the process that occurs in communication, is a communication activity. So referring to the above, it can be described that the trial process occurs through the communication process as the trial process involving the communication element as an important dimension in the trial.

Communication activities in the trial hearings are identified in recurring events, in the ethnography of communication is the communication event characterized by the communication behavior of a community group, in this case, is the legal Advisor with the defendant. Communication events such as any events or events that they experienced, related to the trial process conducted.

Communication Interaction between the Legal Advisor and the defendant in the courtroom when the defense Advisor and the defendant enter the courtroom, either in the trial stage of the indictment, the verdict of evidence, the prosecution hearing, and the verdict. The defendant and the legal Advisor met in the press before the trial began to show the defendant and the lawyers meeting each other, they came to each other and interacted, shook hands and smiled at each other, talking to each other and whispering. This then marks the process of communication between lawyers and defendants in the courtroom. Based on this, the communication between the legal Advisor and the defendant occurred during the trial process, the communication occurred in the form of verbal communication and nonverbal communication.

Based on observations and interviews, communications advocacy incidents with defendants include:

1. Events of communication at the time of meeting and parting in the courtroom.

This communication event before the trial began and there was a courtroom, the defendant and the legal Advisor met in the courtroom, before the trial began to show the defendant and the legal Advisor met each other, they came to each other and interrelated, shook hands and smiled at each other, talking to each other and whispering. And this indicates a form of nonverbal communication conducted by a legal Advisor with the defendant in the courtroom.

2. Events of legal advisory communications with the accused at the time of the hearing

Other communication events occur when the defendant will invoke an exception, an examination, or and a Pledoi in the hearing 


\subsection{A Pattern of Communications Advocacy of Legal Advisor with Defendant at the Courtroom.}

The defendant's accepting activities by legal Advisor in the trial are conducted through communication, courtroom communication. Mentoring is intended to accompany the defendant during the trial. The court proceedings took place in the indictment hearing, the hearing, the prosecution and the verdict.

Based on the Information that, legal Advisor as a legal Advisor provides legal assistance through advocacy as a form of communication that appears in court proceedings. through advocacy. The advocacy in question is a form of legal Advisory communication for the defendant, with the primary objective of providing understanding to the defendant and proving the innocent defendant. Advocacy in question is to provide assistance, provide information about punishment, provide information about the possibility. Advocacy in the court as a manifestation of the application of the rights of defendants in court.

The form of communication in the advocacy is divided into two namely verbal communication and nonverbal communication. Verbal communication is illustrated when the legal Advisor explains to the court the case of the defendant or complains the defendant through verbal or asked questions. While nonverbal communication in the pattern of advocacy is done for through the sound of a cough, eye code, and glance.

The pattern of advocacy begins when the legal Advisor is authorized by the defendant to assist in the case. This communication pattern occurs mainly related to the prosecutor's indictment, the defendant's examination, and the Witnesses, and answer the prosecutor's demand. Here's the explanation:

1. Context Responding to prosecutor's indictment (Exception) When the Public Prosecutor submits the indictment to the defendant, and the indictment has been read out, the defendant's rights then convey the answer to the indictment through this request from panels of judges. The defendant's reply to the prosecutor's demand is referred to as an exception. The exception is the defendant's answer to the alleged accusation by the public prosecutor. The exception is one of the stages of the proceedings in court in a criminal case. The Criminal Procedure Code gives the right of defendants to submit common objections also called an exception to the charges of the Public Prosecutor. How the form and composition of the exception KUHAP do not regulate it. Similarly, what should be included in the exception is not specified by the KUHAP. This means that the form and composition and content of the exceptions are dependent on the Defendant or his legal Advisor with the main limit of exception is not the subject matter of the case.

2. The context of Defendant and Witness Examination After the Public Prosecutor's opportunity to prove the problem or mistake of the defendant in the courtroom, it is the defendant's turn to explain the case in the indictment accompanied by the Legal Advisor. Among them are (1) The filing of witnesses who lighten the defendant. (2) Submission of other shreds of evidence to support the argument of a defendant and legal Advisor. (3) Examination of the Defendant

3. Responding to the Public Prosecutor's claim (Pledoi). The defendant filed a defense (Pledoi), on a lawsuit filed by the Prosecutor. Pledoi can be done orally or in writing. If the defendant makes an oral defense, the defendant generally enters his / her defense while sitting in the examination seat and the contents of the defense are recorded by the clerk in the minutes of the hearing, also recorded by the parties concerned, including the judge. However, if the defendant filed a written defense, the defendant read out his defense. After the defendant has read the defense or if the defendant has given the legal Advisor the fullest, the chief judge asks the legal Advisor, whether it is ready with the defense note. When the legal Advisor is ready with the defense, the presid- ing judge immediately invites the defense Advisor to read out his or her defense. The procedure of reading the defense by the legal Advisor is the same as the filing of an exception. After the defense memorandum readout is completed, the script of the defense (original) is submitted to the presiding judge, and the copy is submitted to the prosecutor and the defendant. Further, the Chief judge asked the public prosecutor whether the defendant would file a response to the defense of the defendant / legal adviser (Replik). If the prosecutor will respond to the defense of the defendant / Legal Advisor, the presiding judge shall give the prosecutor an opportunity to file a reply.

\section{Conclusion}

Discussions between the legal Advisor and the defendant held that interaction and communication took place in the court, as seen from the process of the two when meeting each other in the courtroom, facing each other, greeting each other, sharing smiles with each other, interacting with each other. This confirms that advisory communication with the defendant is an important part of the trial so as to provide an overview of the habits that shape the advocacy communication pattern in the courtroom, especially in Indonesia. The pattern of advocacy communication is used to help provide an understanding of the law, provide information about punishment, provide information about possible punishment to be received by the defendant.

\section{References}

[1] Harahap MY. Pembahasan permasalahan dan penerapan KUHAP Sinar Grafika; 2000

[2] Nomor U-URI. Tahun 2003 tentang Advokat. Lembaran Negara Republik Indonesia Nomor.49.

[3] Flower L. Doing loyalty: Defense lawyers' subtle dramas in the courtroom. Journal of Contemporary Ethnography. 2016:0891241616646826.

[4] Aronsson K, Jönsson L, Linell P. The courtroom hearing as a middle ground: Speech accommodation by lawyers and defendants. Journal of language and Social Psychology. 1987;6(2):99-115.

[5] Bungin B. Analisis data penelitian kualitatif: PT RajaGrafindo Persada; 2007.

[6] Mulyana D. Metodologi penelitian kualitatif. Bandung: Remaja Rosdakarya. 2001

[7] Mulyana D. Ilmu komunikasi: suatu pengantar: Remaja Rosdakarya; 2000

[8] Devito JA. Komunikasi antar manusia. Jakarta: Professional Books. 1997.

[9] Spradley JP, Elizabeth MZ, Amirudin. Metode etnografi1997.

[10] 10. Spradley JP. The ethnographic interview: Waveland Press; 2016.

[11] Littlejohn SW, Foss KA. Encyclopedia of communication theory: Sage; 2009.

[12] Ibrahim AS. Panduan Penelitian Etnografi Komunikasi. Surabaya: Usaha Nasional. 1994.

[13] Savile-Troike M. The ethnography of communication. Oxford; 1982.

[14] Effendy OU. Komunikasi Teori \& Praktek. Remaja Rosdakarya Bandung. 1989.

[15] Creswell JW. Research design: Qualitative \& quantitative approaches: Sage Publications, Inc; 1994.

[16] Sugiyono MPK. kualitatif dan R\&D. Bandung: Alfabeta. 2008;124

[17] Moleong LJ. Metodologi penelitian. Bandung: PT Remaja Rosda Karya. 1999

[18] Sugiyono D. Metode Penelitian. Bandung: CV Alvabeta. 2000.

[19] West R, Turner LH. Pengantar teori komunikasi: analisis dan aplikasi. Jakarta: Salemba Humanika. 2008. 